\title{
O SENADOR CORREIA
}

\section{Jurista - político - administrador \\ Alfredo Valadão}

Prosseguindo no estudo que, ùltimamente, na minha elaboração histórica, venho realizando de modo especial, sôbre vultos nacionais, trato hoje, na oportunidade do cinqüentenário do seu falecimento, dêsse que foi o Senador Correia, destacando-se, ao mesmo tempo, no cenário político e no cenário cultural do império, certo redobradamento no cenário cultural, e em que ainda continuaria a destacar-se depois da República, até desaparecer em 11 de julho de 1905.

E a reerguê-lo do olvido inexplicável, no qual, de algum tempo, o têm deixado os nossos escritores.

Nas longas pesquisas a que, durante alguns meses, me consagrei para a organização desta pesquisa, o mais antigo trabalho a seu respeito, que pude conhecer, foi o Esbôço Biográfico, da autoria de Amaro da Silveira, inserto na introdução dêsse volume publicado, em 1884, por João Antonio dos Santos Cardoso, sob o título Conferências e outros trabalhos do Conselheiro Manuel Francisco Correia, volume o mesmo existente na Biblioteca Nacional, bem como na do Instituto Histórico. Seguiu-se-lhe essa Biografia, também existente na Biblioteca nacional publicada em 1900, da lavra do conhecido historiador Moreira de Azevedo feita para a Escola Barão do Rio Doce. Apareceu depois o elogio proferido em 1905, no Instituto Histórico, pelo seu ilustre orador Sousa Pitanga. Finalmente, ainda a seu respeito, alguns traços biográficos foram consagrados por Almeida Nogueira nas Tradições e Reminiscências 
da Faculdade de Direito de São Paulo, por Blak, no Dicionário Bibliográfico. É para observar também que o fichário da Biblioteca Nacional registra o seguinte trabalho - Biografia do Conselheiro Manuel Francisco Correia - Discurso proferido por $J$. B. Otoni - 1915; trabalho que entretanto não pude conhecer, por se achar na encadernação, ao que me informaram. Devo ainda referir que a Memória de Paula Freitas, sôbre a Associação Mantenedora do Museu Nacional, escrita em 1890, e existente na Biblioteca Nacional, onde a consultei, deixa muito em foco uma das grandes atividades da vida cultural de Correia.

Especialmente quanto à época em que êle desapareceu, além daquele elogio produzido no Instituto Histórico pelo seu orador, fez-lhe o Jornal do Comércio, o necrológio em sua $G a$ zetilha, certo em breves considerações, mas traçando a linha geral da sua personalidade. No Congresso Federal, na tribuna da Câmara, Carlos Cavalcanti, deputado pelo Paraná, exaltou-lhe a memória em rápido, mas animado discurso, focalizando os pontos culminantes da sua vida. Mas decepciona o que ocorreu no Senado, naquela Casa a que, segundo para adiante ficará visto, estivera êle com brilho ligado no Império, o mais assíduo, o cotidiano, pode-se dizer, frequentador da tribuna, dando expansão à sua cultura e ao seu patriotismo no debate dos mais variados assuntos. Era de esperar, pois, que em homenagem à sua memória se erguessem muitas vozes. Entretanto só uma se fêz ouvir, a de Joaquim Katunda, ilustre senador pelo: Ceará, porém proferindo estas brevíssimas palavras, que constam dos Anais: "Aproveitando a ocasião, Sr. Presidente, para desta tribuna pedir ao Senado que mande consignar na ata da sessão de hoje um voto de pesar pelo falecimento do notável homem público, Sr. Manuel Francisco Correia, ex-senador do Império pela então Província do Paraná e que tantos e tão valiosos serviços prestou á sua terra e ao país".

Estendi ainda as pesquisas, como se impunha, pelos Anais do Parlamento do Império, e pela Revista do Instituto Histórico, além de sua Biblioteca.

Organizei afinal este trabalho, dividido em -três partes. 
Na primeira, estudo a figura do notável brasileiro, no Império, principalmente quanto à vida política e administrativa ; na segunda, ainda no Império, especialmente quanto à vida cultural, chegada ao ápice nas "Conferências da Glória"; e, por fim, na terceira, quanto à vida em geral da República.

Filho do comendador Manuel Francisco Correia Júnior c D. Francisca Pereira Correia, nasceu êle, Manuel Francisco Correia Neto, a 11 de novembro de 1831 na então vila Paranaguá, integrada na Comarca de Curitiba da Província de São Paulo, comarca essa em 1853 elevada a Província, hoje Estado do Paraná; nasceu naquela então vila, mas já fundada em 1648 , de vivos títulos históricos, ainda recentemente cantados pelo Professor Oscar Martins Gomes, da Universidade do Paraná, em uma das passagens de seu poema Goiabang, comemorativo do Centenário daquele Estado.

"Seu pai", diz Amaro da Silveira no citado Esbốço Biográfico, "conceituado negociante, logrou até certa época prosperidade no comércio, chegando a acumular consideráveis recursos. Havendo porém aderido ao partido legalista, e assumido o comando militar de Paranaguá, quando arrebentou a revolução paulista de 1842 , - revolução que tendia a lastrar para 0 sul, onde por aquêles tempo era o Império enèrgicamente abalado; de tal modo devotou-se ao empenho de organizar a defesa da comarca, ameaçada pelas fôrças revolucionárias, que nessa tarefa compromenteu a prosperidade de seus negócios".

"A comenda da ordem brasileira de Cristo fora-lhe conferida como prêmio de seus sacrifícios, e em conseqüência dêles veio terminar pobre uma existência de aturado e honesto trabalho".

Apesar destas circunstâncias, não faltaram ao jovem Manuel Francisco Correia os meios para encetar desde logo os estudos a que havia sido destinado, e que chegariam a conquista, em 1854, do bacharelado em direito pela Faculdade de 
São Paulo; meios êsses fornecidos por seu avô, a quem aliás, logo que teve recursos, se apressou a indenizar.

Feitos os estudos primários na terra natal, chega aos doze anos a Nova Friburgo, onde cursa até 1845 as aulas do conceituado Educandário ali existente, sob a direção de John J. Freese, dêsse "abonado inglês que a tantos cidadãos teve a glória de educar para bem do Brasil".

Brilhante foi o seu curso, como deixa ver o fato de que dá notícia o esscritor em causa.

"Em vésperas de retirar-se do internato Freese, e no dia em que completava 14 anos, recebeu o aluno Correia uma enciclopédia Maunder, em cuja primeira página escreveu o ofertante: "Ofereço êste livro ao meu jovem amigo e discípulo, Manuel Francisco Correia Neto, o primeiro entre os meus alunos, como pequena prova da minha sincera consideração, a qual junto os meus ardentes desejos de que êle veja muitas vêzes repetir-se feliz êste dia, e viva para realizar minha cordial esperança de que será uma honra para a sua família, um crédito para si mesmo e um benefício para o seu país" .

Esperança esta que foi uma profecia.

Transferindo-se em 1846, com matrícula do $4 .^{\circ}$ ano, para êsse grande, modelar Educandário, o Colégio Pedro II, criação do "gigante intelectual", que foi Bernardo de Vasconcelos, continuou aí a distinguir-se o aluno Correia.

Moreira de Azevedo, por sua vez, e forrado no seu testemunho pessoal, exalta-lhe a figura: "Tivemos a glória de ser seu condiscípulo e assistimos aos seus triunfos e conquistas na carreira das letras".

$\mathrm{E}$ dando ainda notícia de uma outra homenagem que êle recebera em Nova Friburgo: "Assistindo aos seus exames no Colégio Freese, o Ministro russo Lamonosoff oferta-lhe também um livro com lisonjeira dedicatória".

Conquistando em 1849, nêsse Colégio Pedro II, a láurea ào bacharelado em letras, segue em 1850 para São Paulo, onde se matricula na Faculdade de Direito, formando-se em 1854. 
"Pertence ao escol da Faculdade"; essa a síntese tão expressiva, com que nas suas clássicas Reminiscências da mesma Faculdade, Almeida Nogueira inicia a página descritiva da sua figura.

Síntese consubstanciando o conjunto dos seus títulos intelectuais revelados tanto no estrito campo jurídico-social, como no campo literário, no qual a mocidade acadêmica ali brilhantemente se exercitava com oradores, conferencistas, jornalistas, romancistas, e sobretudo poetas que fizeram época.

Certo, o mesmo Almeida Nogueira considera a José Maria Correia de Sá e Benevides (mais tarde um dos maiores professôres da Faculdade), como o primeiro estudante dessa turma acadêmica de 1850-1854, "sem embargo, da competência de Manuel Francisco Correia".

Explicando: "A natureza dotara a Correia da mais rica imaginação, porém a Benevides, da maior perpicácia. Ambos oradores. Correia político, poeta e literato; Benevides jurisconsulto, crítico e jornalista". E salientando que os mesmos eram êmulos desde o Colégio Pedro II.

A oratória foi deveras a nota dominante da obra literária de Correia.

"O verbo", diz ainda Almeida Nogueira, "saía-lhe em ondas e impetuoso. Prodigalizava a apóstrofe e a hipérbole".

"Quando falava, as faces congestionavam-se, a voz era tonitroante e a gesticulação animada e combativa".

"Seu discurso era um requisitório violento e carregado de imprecações".

"Fôra talhado naturalmente para a tribuna de combate cu para os assuntos mavórticos".

"E a sua atividade se estendia pelas reuniões acadêmicas, pelos comícios populares e pelos espetáculos de gala.

E cultivá-la-ia, a oratória, para sempre, e ilustrada com a exibição dos mais variados conhecimentos, já na tribuna parlamentar, já, e sobretudo, nas célebres "Conferências da Glória". 
Certo, ao lado dessa tão alta revelação no campo da oratória, tentou aparecer em outros gêneros literários. Compôs uma pequena comédia sob o título Magnetismo, e ainda um romance intitulado A Praia da Glória. Esta produção "teve notoridade seródia, pois foi reproduzida vinte anos depois nas colunas da Reforma, quando Correia no ministério, e com o fito de ridicularizá-lo por aquêle pecado dos seus verdes anos".

Disso dá notícia o mesmo Almeida Nogueira, e que, como ficou visto, qualificou-o ainda como poeta, mas certo no sentido amplo da palavra, da viva imaginação que enriquecia sua oratória.

Não pude conhecer-lhe alguma produção poética.

Pelo que respeita ao campo jurídico, o "estudante de escol", a quem apenas o seu colega Benevides superava, teria na vida prática de salientar-se, a cada momento, em cargos administrativos, chegando ao Conselho de Estado, bem como no Parlamento, e, afinal, nos trabalhos do Projeto do Código Civil.

Graduado que foi, em 1854, pela Faculdade de Direito de Sảo Paulo, entra imediatamente para a vida prática.

Não escolhe, porém, carreira da advocacia, adequada à sua oratória, mas a carreira administrativa, pois baldo de recursos, como assinala um de seus citados biógrafos, precisava de imediatos vencimentos, que só a mesma assegurava.

Escolhe a carreira administrativa, mas dentro em algum tempo adjuntada da carreira política, onde daria largas àqueles seus primorosos dotes oratórios.

Nomeado 2..$^{\circ}$ Oficial da Secretaria da Fazenda, por decreto de 14 de dezembro daquele ano de 1854, foi promovido logo, em 1855, a chefe de seção, pôsto no qual passou em 1859, para a Secretaria do Império, e sendo em 1860 nomeado Secretário da Província do Rio de Janeiro, tais os seus méritos.

Não obstante o perfeito desempenho que vinha dando a êsse cargo, volta breve para a Secretaria do Império, onde os seus serviços eram considerados indispensáveis. 
E aí recebe em 1861 a nomeação de chefe de Seção dos Negócios Eclesiásticos, onde permaneceria até 1871, quando, por decreto da referenda do inclito João Alfredo, ministro do Império, - e ao qual tão estreitamente se ligaria, pela consonância dos seus ideais sôbre a instrução pública e sôbre a abolição, é nomeado chefe da Repartição Geral de Estatística, então instalada.

Foi êle de 1860 até 1862 oficial de gabinete de todos os ministros do Império que se sucederam, Almeida e Oliveira, Saião Lobato (Visconde de Niterói), Saraiva, e Souza Ramos (Visconde de Jaguari) ; nem faltando que exercesse ainda, interinamente, por certo tempo as funções de consultor jurídico do Ministério da Justiça, no impedimento de José de Alencar.

Pertencente ao partido conservador, então no poder, com o Ministério Caxias, foi a 29 de março de 1862, contando apeínas 32 anos de idade, nomeado presidente de uma das mais importantes províncias do Império, a de Pernambuco, salientando-se, pela elevação com que exerceu o cargo, e ainda pelo acêrto das providências tendentes a conjurar a epidemia do cólera morbo que ali irrompera.

Breve, porém, foi a sua permanência nesse cargo que deixou naquele mesmo ano, pela mutação operada no cenário político do país, com a formação da Liga, ou, por outra, do partido progressista, que se manteria no poder até o ano de 1868.

Reassume, assim, as suas funções de chefe da Seção dos Niegócios Eclesiásticos, do Ministério do Império.

E especializando-se, cada vez mais, no assunto, recebe afinal, em 1868, do então titular da pasta do Império, do Ministério Itaboraí, Paulino José Soares de Sousa, a incumbência de compilar as Consultas do Conselho de Estado, atinentes ao mesmo assunto.

De tal incumbência se desobriga com a publicação de três tomos, o primeiro em 1869, e os outros em 1870, os quais compõem um volume que consultei, existente na Biblioteca dêste Instituto. 
E se reveste, de fato, da maior importância, o seu trabalho, pois a Compilação é acompanhada dos decretos, avisos e circulares, expedidos para a execução das Resoluções tomadas, bem como de várias e interessantes anotações do autor.

Com a ascensão do partido conservador ao poder em 1868, constituído o Ministério Itaboraí, abriu-se para êle, Correia, a plenitude da carreira política.

É logo eleito deputado geral pela Província do Paraná, à legislatura de 1869 a 1872.

E para pertencer a uma Câmara de escol, como a dessa legislatura, na qual o partido conservador dominante conta uma extensa e luzida galeria de jurisconsultos, como, por exemplo, Perdigão Malheiro, Cândido Mendes, Coelho Rodrigues, Andrade Figueira, Ferreira Viana, José de Alencar, Duarte de Azevedo, Tristão de Araripe, João Mendes de Almeida; de oradores, como, por exemplo. Gomes de Castro, Ferreira Viana, Fernandes da Cunha, Andrade Figueira, José de Alencar, Evaristo da Veiga (sobrinho), e êle próprio, Correia; de homens de letras, como, por exemplo, José de Alencar, Barão de Paranapiacaba, Pereira da Silva, Pinto de Campos, Melo Morais; e de figuras políticas que daí em diante, e por tão justos títulos, iriam sendo chamadas a mais altos postos, como, por exemplo, Paulino de Sousa, já deputado em anteriores legislaturas, integrante do Ministério vigente, na pasta do Império, alter- rgo mesmo de Itaboraí, e para ser depois presidente da Câmara, e afinal do Senado, João Alfredo, integrado dentro em pouco tempo no Ministério São Vicente, e a seguir no Ministério Rio Branco, para ser o maior colaborador da sua obra, e tendo mais tarde, em 1888, a glória de ser Presidente do Ministério que promoveu a Lei de 13 de Maio, declarando extinta a escravidão no Brasil, e, finalmente, Joaquim Delfino, Vieira da Silva, Teixeira Júnior, Francisco Belisário, Ridrigo Silva, António Prado. E conta ainda, José Maria da Silva Paranhos Filho (futuro Barão do Rio Branco), essa esperança já então consagrada naquêle Instituto, e destinado a ser, mais tarde, o Deus Terminus das nossas Fronteiras, na feliz expressão de Rui Barbosa. 
Entrando para a Câmara, logo na sessão de 20 de maio já se exibia êle na tribuna, dando expansão à sua cultura jurídica, no trato de um projeto, atinente ao direito penal internacional, trato que ainda mais amplamente se consagraria, estudando a matéria sob os mais variados espectos, quando o mesmo projeto voltou a debate na sessão de 28 de julho.

E na sessão do dia 29, apresentou um projeto sôbre naturalização, o qual, com as emendas ofereciadas no Senado, converteu-se na Lei n. ${ }^{\circ} 1.950$, de 12 de julho de 1871.

Entre os discursos que vai pronunciando daí em diante, pela sessão legislativa do ano em causa, do mesmo modo que pela do ano de 1870, sôbre assuntos administrativos de várias naturezas, deixando à vista a amplitude de sua cultura, são os mais importantes, merecendo especial registro os de 1 de junho de 1869 , e 15 de julho de 1870 , reveladores do seu perfeito conhecimento do complexo assunto da ciência das finanças, na análise da gestão do notável estadista Visconde de Itaboraí, na pasta da Fazenda.

Na sessão legislativa de 1870 , a bem dos interêsses da imigração, apresenta um projeto estabelecendo o casamento civil entre as pessoas de religião diversa da do Estado, mas com o vínculo indissolúvel.

Mais uma vez revelando assim na sua cultura jurídica, inclinação para o direito internacional.

Em 1871, constituído o Ministério de 7 de março, sob a chefia do Visconde do Rio Branco, faz êle parte do mesmo, como titular da pasta dos Negócios Estrangeiros (hoje denominada das Relações Exteriores), que bem se lhe ajustava.

Foi em condições as mais honrosas que ascendeu a êsse pôsto, como dá notícia Moreira de Azevedo, na sua citada Biografia :

"Chamado o Sr. Visconde do Rio Branco em 1871 para organizar Ministério, convidou-o para fazer parte dêle. Recusou essa honra; persistiu o visconde em seu propósito; e, vendo que não o convencia, declarou que ia desistir da tarefa de organizar o gabinete ministerial". 
"Fêz-lhe ver o Dr. Correia que não podia alegar semelhantє razão, visto como era êle partidário decidido do govêrno, prestando-lhe todo o apoio no parlamento, e seria campão dedicado da situação política que ia inaugurar-se".

"Recalcitrava o visconde, e, conhecendo que nada conseguira, declarou que além de haver o Imperador recebido a notícia do falecimento de sua filha em Viena, experimentaria outro desgôsto no mesmo dia, por haver falhado a combinação ministerial".

"Não desejando aumentar a aflição do pai e soberano entrou Manuel Francisco Correia para o Ministério, cabendo-lhe a pasta dos negócios estrangeiros".

E relevante foi o serviço que assim êle, Correia, prestou ao Brasil, concorrendo para que se levasse a efeito a organização dêsse Ministério, destinado à glória de um grande lance na benemérita obra da extinção do elemento servil, e a realizar importantes empreendimentos quanto ao progresso material do país e à instrução pública.

Sérias dificuldades, porém, cercavam o desempenho da pasta que lhe foi confiada (essa dos Negócios dos Estrangeiros), pelo que se referia ao assunto da, como chama Joaquim Nabuco, "questão argentina", quer dizer a que se originou da celebração dos Tratados de paz com o Paraguai".

Nesse delicado assunto, momento ocorreu, em que o Brasil esteve mesmo a pique de uma guerra com a Argentina, evitada pela "Dignidade, calma e paciente", com que se houve o Govêrno Imperial, como considera êsse notável historiador, na sua obra Um Estadista do Império.

$\mathrm{E}$ a respeito teve êle Correia de responder, como revelam os Anais, a fortes interpelações que da tribuna da Câmara foram feitas por Francisco Belisário, da dissidência conservadora, e Silveira Martins, das hostes liberais.

Mas impossível é desconhecer a parte preponderante que no curso e na solução dessa "questão argentina", teria tido o Visconde do Rio Branco, o grande e profundo especialista nos assuntos do Prata. 
Joaquim Nabuco chega mesmo a dizer: "Num gabinete presidido pelo Visconde do Rio Branco está visto que os papéis diplomáticos importantes do Govêrno com relação ao Prata emanavam dêle. As notas a Tejedor têm todos os sinais da sua mão, foram lidas depois por êle com Conselho de Gabinete, e submetidas, como todos os documentos, ao exame e apreciação do Imperador. Na Câmara e no Senado foram francamente atribuídas, e com razão a Rio Branco".

Certo, porém, que Correia lhe responderia em publicação de 1899, como para adiante deixarei visto.

Sôbre outros assuntos tratados pelo ilustre brasileiro na gestão de sua pasta, e que deixam muito em foco a sua competência, já bem soube especialmente apontar Sousa Pitanga, no seu referido elogio, feito nêste Instituto, a solução dos conflitos suscitados com a França e com a Bolívia, e o notável memorandum dirigido ao Govêrno da Alemanha sôbre colonização alemã no Rio Grande do Sul, e o caso de oficiais alemães da corveta Nymphe, ancorada no pôrto do Rio de Janeiro, documento êsse que determinou a demissão dada pelo Príncipe Bismarck ao Ministro Solms.

Restrinjo-me a esta citação, deixando de desenvolver a matéria, pela mesma razão por que não o fêz Sousa Pitanga, a "de que em Correia, a nota mais sonante da sua útil existência foi a sua dedicação extrema e carinhosa pela causa da instrução popular".

Em 1873, deixa êle a pasta, sem dizer a razãa de seu ato; mas sem se separar da maioria.

Moreira de Azevedo, porém, assim a aponta: "Divergindo sôbre o provimento da Legação de Londres, sustentando não ser decente, além de ser prejudicial á administração do país, o recebimento, sem autorização legal, de porcentagem pelos representantes do Império ao contraírem empréstimos, pediu a sua exoneração de Ministro da Corôa".

Deixa então a pasta, mas para dentro em pouco ascender a outro alto pôsto, o da presidência da Câmara, que exerceu durante as sessões legislativas de 1874 e 1875, da 15. ${ }^{\text {a }}$ legislatura, com todo brilho. 
$\mathrm{E}$ disto sendo um precioso testemunho, na sessão de 9 de cutubro de 1875 (última da mesma legislatura), essa manifestação assinada por todos os deputados presentes da maioria da dissidência e da oposição, em número de quase sessenta: "Os abaixo assinados, deputados á Assembléia Geral Legislativa, presentes na sessão de hoje, não podendo, por falta de número, requerer em assembléia que se consignasse na respectiva ata um voto de louvor e agradecimento ao atual presidente, Conselheiro Manuel Francisco Correia, pela sabedoria, retidão e imparcialidade com que dirigiu os trabalhos parlamentares durante tão largo espaço, o fazem por meio desta manifestação, a qual deverá ser transcrita no jornal que publica os trabalhos da casa e nos anais desta sessão".

Afinal, em 1877, apresentado em iista tríplice (e em primeiro lugar), pela Província do Paraná, é nomeado senador.

$\mathrm{Na}$ sua carreira de funcionário público passara em 1871, como já ficou visto, para o cargo de chefe da Repartição de Estatística, então instalada, cabendo-lhe dirigir desde 1873 os trabalhos do primeiro recenseamento da população do Império: cargo em que se apresentaria em 1879, extinta aí a mesma Repartição.

Foi a 10 de abril daquele ano de 1877 , que tomou êle possc da sua cadeira de senador, e para iniciar desde logo uma importante e indefessa colaboração, que só haveria de cessar, quando extinta essa Casa em 1889, com o advento de República.

Proverbial a sua assiduidade à tribuna, senhor de tôda a ordem do dia; e que agora pude conhecer diretamente, manuseando os Anais.

A respeito é êle, de fato, uma figura única na nossa vida parlamentar.

Nullus est dies quo non dicam pro reo - exclamava com orgulho o incomparável Cícero, sôbre a sua atividade de advogado.

Parodiando-0, bem poderia êle exclamar, de igual modo, sôbre a sua assiduidade na tribuna perlamentar: nullus eșt dies quo non dicam pro patria. 
E tribuna a qual subia, realmente, possuído dos mais acrisolados sentimentos patrióticos.

Não era um exibicionista; não procurava apenas os assuntos retumbantes, para maior notoridade de seu nome.

De todos tratava, brilhantes ou não, grandes ou pequenos, que lhe parecessem interessar ao progresso material e moral do país. E tratava no sentido mais amplo, compreensivo dos assuntos diretamente nacionais, como dos assuntos provinciais, z ainda dos municipais.

Ao mesmo tempo que compreensivo dos assuntos de tôdas as naturezas, políticos, internacionais, administrativos, jurídicos, culturais, econômicos, industriais, financeiros.

Sôbre o seu poder de assimilação, no trato das matérias, fere muito especialmente a vista, o mesmo, quanto aos longos debates em que se empenhou, com perfeito conhecimento de causa, relativos aos assuntos técnicos do Ministério da Guerra e do Ministério da Marinha.

Paralelamente a essa atividade parlamentar, a uma outra, também com a maior dedicaçãço se consagraria êle, na sua carreira política, desde 1886, a desenvolvida no Conselho de Estado, para o qual fôra então nomeado.

Entra para êsse "crisol dos estadistas do Império", designado para a seção dos negócios da guerra e da marinha. $\mathrm{E}$ de certo tempo em diante, como refere Moreira de Azevedo, é relator da mesma, reunindo-se com seus colegas, uma vez por semana na Secretaria da Guerra, para examinar as questões e assenatr nos pareceres, que tinham de ser sujeitos à deliberação do govêrno.

Refere ainda Moreira de Azevedo, que a seção em causa, da marinha e da guerra do Conselho de Estado, reuniu-se pela última vez em 14 de novembro de 1889, isto é, na véspara da proclamação da República e que deixou resolvidos todos os assuntos submetidos à sua consulta; a sua pasta ficou vazia.

E a essa exemplar atividade, aí desenvolvida pelo ilustre brasileiro, devia corresponder o brilho de seus pareceres, à vis- 
ta daqueles perfeitos anteriores conhecimentos revelados nos debates parlamentares.

Finalmente, a sua figura política ainda esteve em muita evidência no último ano do Império, em 1889, quando foi o primeiro estadista a quem o Imperador cometeu a imcumbência de organizar um novo Ministério conservador, em substituição ao Ministério João Alfredo. Não levando a efeito essa incumbência ao que parece, porque se mostravam irreconciliáveis as duas correntes em que se achava dividido o partido, a chefiada por Paulino de Sousa e a chefiada por João Alfredo; e tanto assim que os estadistas a seguir convidados, Teixeira Júnior e Vieira da Silva, também não puderam levar a efeito a mesma incumbência; havendo o Imperador afinal chamado ao poder o partido liberal, constituído o Ministério Ouro Prêto.

$\mathrm{E}$ a alta consideração política e pessoal, que the dispensava o Imperador, teve a mais expressiva significação, quando êste, no dia 15 de novembro, no momento angustioso por que estava passando, o convida para uma conferência a sós no Paço da Cidade, da qual para adiante darei notícia.

Encerrada, que acaba de ficar, a primeira parte dêste trabalho, passo à segunda, a relativa especialmente à vida cultural do ilustre brasileiro, fora daquelas brilhantes manifestações na sua vida política, reveladas na tribuna parlamentar.

A atividade por êle desenvolvida nesse campo foi multiforme, intensa e brilhante.

Alteou-se naquelas célebres "Conferências da Glória", instituídas em 1873; na Associação Promotora da Instrução, fundada em 1874; na Escola Normal, aparecida também nêste mesmo ano; na Associação Mantenedora do Museu Escolar Nacional, vinculada ao Congresso de Instrução, de 1883; e na Sociedade Amante da Instrução".

E se manifestou ainda, em outras situações, embora com menos intensidade. 
Sôbre tudo isso, vou falar, mas invertendo a ordem cronológica, para falar por último, e amplamente, sôbre as "Conferências da Glória", nota a mais elevada de tôda essa atividade desenvolvida pelo eminente brasileiro.

A Escola Normal, primeira no gênero aparecida na capital do Brasil, fundou-a êle a 25 de março do referido ano de 1874.

Encerrou-se em dezembro do ano seguinte, mas como salienta Moreira de Azevedo, tratando da mesma, "apesar da sua pouca duração, prestou serviços à instrução, habilitando professôres e professoras, e despertando a ação oficial em favor desta questão primária do ensino".

"Facultado ao govêrno pelo poder legislativo, o estabelecimento de escolas normais, a instituição particular suspendeu os seus trabalhos iniciados, escreve o Conselheiro Correia, ùnicamente para preencher sensível lacuna na organização do ensino de um município tão populoso e tão ilustrado como o da Côrte".

A Associação Promotora da Instrução, representante da fusão das antigas associações Promotora da Instrução de $\mathrm{Me}$ ninos e Promotora de Instrução de Meninas, êle a fundou em 1 de janeiro daquele memo ano de 1874, para difundir o ensino primário e secundário pelas classes populares.

$\mathrm{E}$ os seus altos destinos já foram muito bem consubstanciados por Moreira de Azevedo, na sua citada Biografia.

Abordando o assunto da mesma, assim inicia as suas considarações: "Guiada pelo tino e perseverança do seu instituidor, e bafejada pelo favor público, começou a progredir. Era nobilíssima a sua missão, patriótica as suas aspirações, o ensino do povo".

E a seguir faz a síntese da sua vida, do seu contínuo progresso, pondo em foco a elevação dos seus moldes e a extensão de suas brilhantes realizações.

As Escolas por ela mantidas, em número de quatro, servindo às diversas zonas da Cidade, situavam-se, respectiva- 
mente, em São Cristovão, Vila Isabel, rua do Lavradio, e rua São Salvador (e, a aqui situada, vindo a chamar-se Escola Senador Correia).

Fundou ainda, a mesma Associação, em 1882, uma biblioteca, inaugurada com a presença de D. Pedro II, que aliás nunca falhava em atos de tal natureza.

Os prédios, em que as escolas funcionavam, eram belos edifícios para a época, e havendo sido construídos sob a direção, gratuita, do notável engenheiro Paula Freitas.

Aos alunos fornecia a Associação também gratuitamente livros, cadernos, papel, penas, lápis e o mais necessário ao ensino. Tôdas as escolas estavem guarnecidas de mapas, estantes, quadros e aparelhos, as mobílias eram modernas e apropriadas às salas de estudo.

$\mathrm{E}$ tudo isso que acaba de ser pôsto à vista, se fazia sem subvenção alguma dos cofres públicos, "por entender o presidente Correia que no serviço que ela (Associação) presta são os esforços e sacrifícios individuais que denotam o vigor cívico das nações".

Aos alunos mais distintos eram conferidos prêmios anualmente.

Havia também prêmios de bom procedimento, prêmios de caráter. $\mathrm{E}$ nas salas de estudo das Escolas se via mesmo esta máxima seu fundador:

"Se todos não podem ter talento,

todos são obrigados a ter caráter".

Finalmente, sôbre a afluência às escolas, assim pode informar Moreira de Azevedo: "Cada ano aumentava a matrícula dessas escolas, onde milhares de meninos e meninas iam beber ensino".

Passo a falar agora a respeito da atividade de Correia, na Associação Mantenedora do Museu Escolar Nacional.

Em 1883, reuniu-se no Rio de Janeiro um Congresso de Instrução, de que faziam parte os nossos maiores especialistas 
no assunto, em qualquer de seus ramos, e cujos Anais existem na Biblioteca dêste Instituto, onde os consultei, bem como na Biblioteca Nacional.

Do mesmo fôra êle Correia um dos propugnadores em interessante Conferência proferida na escola da Glória, em 27 de março de 1881; e foi o $2 .^{\circ}$ vice-presidente.

Certo, êsse Congresso apenas realizou sessões preparatórias, por haver sido adiado pelo Govêrno, como já significou Paula Freitas na introdução da sua citada Memória, sôbre essa Associação em causa; só lhe tendo sido possível organizar, por intermédio das suas diferentes comissões científicas, os pareceres relativos a cada uma das teses propostas ao seu exame.

Mas tais pareceres são brilhantes, honrando, sobremodo, a cultura brasileira da época, segundo também já significou êste escritor, e a êsse juízo, acrescento que muitos dêles constituem lições que até hoje se impõem.

Nas mesmas referidas sessões preparatórias, seu presidente, o Conde d'Eu, propôs "que se oficiasse ao Govêrno solicitando autorização para se levar a efeito, ao mesmo tempo que o Congresso, e no edifício em que êste funcionar, uma Exposição Yedagógica, a exemplo das que se realizaram em Paris no ano de 1878 e em Bruxelas no ano de 1880".

Proposta unânimemennte aprovada; e a que o Govêrno imediatamente aderiu, oficiando às Legações Brasileiras em vários países da Europa e da América, a fim de obter-se a remessa de objetos e publicações que pudessem interessar à mesma exposição.

Sendo ainda para referir que uma daquelas teses do Congresso, apreciadas em importantes pareceres, versava mesmo sôbre Exposição Pedagógica, assim como sôbre Museu Pedagógico.

A convocação do Congresso fôra feita pelo Govêrno, e a realização da Exposição ficaria também a seu cargo; mas ao mesmo tempo que êle adiou aquêle certame, adiou essa Exposição. 
A Diretoria do mesmo, informa ainda Paula Freitas, "prevendo o efeito moral que o malôgro da Exposição teria naturalmente de causar nos países estrangeiros, ofereceu-se ao Govêrno para realizar a emprêsa por meio de donativos que trataria de obter".

Aceito pelo Govêrno o oferecimento, os membros dessa Diretoria, Conde d'Eu, Visconde de Bom Retiro, Correia, Leôncio de Carvalho e Franklin Dória, constituiram-se, imediatamente, em comissão, sob título de Comissão Diretora da Exposição Pedagógica, e trataram de realizar por todos os meios ao seu alcance a incumbência que haviam tomado sôbre os ombros".

E assim a Exposição, "que encetara os seus trabalhos com caráter oficial, passou a ser um cometimento realizado ùnicamente com o produto de generosas contribuições de iniciativa particular"; merecendo ainda registro, que foi a primeira das do seu gênero, destinada exclusivamente ao magno assunto do ensino primário, dentre as que se haviam efetuado em vários países da Europa e da America.

Compareceram à mesma as seguintes nações: Estados Unidos, Chile, Argentina, Uruguai, Alemanha, Austria, Hungria, Bélgica, França, Espanha, Inglaterra, Itália, Portugal, Suécia \& Suiça.

A sua inauguração se verificou solenemente a 29 de julho daquele ano nos salóes da Imprensa Nacional, e com a presença da Família Imperial.

Discursou o Conde d'Eu, presidente da Comissão Diretora.

Congratulou-se com a nação pelo auspicioso acontecimento, tanto mais quanto devido à iniciativa particular; e pondo em foco, aquela referida primazia do Brasil, no consêrto internacional, sôbre a matéria pedagógica, no que tange à escola do objetivo a que se circunscreveu a Exposição, isto é, do ensino primário.

$\mathrm{E}$ assim se manifestou sôbre o concurso trazido pelas citadas nações estrangeiras: "O Govêrno e povos de muitos países amigos concorreram para êste certame com material, de- 
monstrando pelo aprêço dado ao convite do Brasil, a consideração de que goza o nosso país entre os que mais adiantados se acham nos diversos ramos dos conhecimentos humanos, e permitindo-nos apresentar aos nossos concidadãos uma instrutiva coleção de publicações e objetos de todo o gênero, próprios para o ensino primário dos diversos graus, objetos que tendo na sua maior parte de ficar no Brasil, graças à generosa cessão de seus expositores, virão a constituir importante núcleo para a utilíssima criação de um Museu Pedagógico".

Sob a impressão daquele importante parecer formulado no Congresso Pedagógico, das conferências sôbre a matéria efetuada na Sociedade Promotora de Instrução, e dessa manifestação do Conde d'Eu, operou-se, no seio da Comissão Diretora de Exposição forte movimento pela criação em causa, pleiteando um Museu Escolar Nacional permanente, em que se colecionassem não só os objetos que figuravam na Exposição, como também os que depois se adquirissem.

$\mathrm{E}$ por dois de seus membros, Franklin Dória e Correia, sendo a idéia defendida na Câmara e no Senado, partindo do primeiro à apresentação à Câmara de um projeto, com o respectivo plano, para a realização oficial de tal desideratum.

Não sendo, porém, possível, como considera Paula Freitas, visto faltarem poucos dias para a conclusão dos trabalhos anuais da Assembléia Geral Legislativa, que ela tivesse tempo de decretar o que entendesse em sua sabedoria, e por outro lado, reconhecendo-se a urgência do caso, resolveu a Comissão Diretora oferecer os seus serviços ao Govêrno Imperial, para efetivar a idéia, e que, de acôrdo com a sugestão de Correia aceitos que fôssem os mesmos, se tratasse da formação de uma associação de caráter literário, a exemplo do que se tem praticado nos países adiantados, a qual tomaria a seu cargo a manutenção do Museu.

Imediatamente se verifica a anuência do Govêrno Imperial; e imediatamente a Comissão começa a agir.

Já a 30 de setembro, no ato do encerramento da Exposição, com a presença da Família Imperial e ilustre assistência, 
Correia, vice-presidente da mesma Comissão Diretora, profere brilhante discurso, onde considera:

"Tendo-se coligido com tanto trabalho numerosos e importantes espécimes de tudo que interessa ao melhor aproveitamento do ensino, dever-se-á consentir que se extinga tão abundante riqueza custosamente reunida, não restando da Exposição Pedagógica senão uma reminiscência saudosa? Dever-se-á consentir em que os frutos de tão profícuo trabalho, que podem também aproveitar às gerações futuras, se dissipem, como fôlhas de árvores sêcas que o tufão atira para pontos diversos e runca mais se encontram? Seria imperdoável".

"Por que não criar definitivamente um Museu Escolar, imitando o recomenável procedimento de outras cidades, $\mathrm{Pa}$ ris, Berlim, Bruxelas, Viena, Buda-Pest, São Petersburgo, Amsterdam, Rotterdam, Munich, Dresde, Zurich e Berna"?

"Convém não perder o momento".

"Devemos recordar-nos de que foi com os elementos com que a Bélgica concorreu à Exposição Universal de Paris, que se fundou o Museu Escolar de Bruxelas, inaugurado a 24 de agôsto de 1880".

Depois de outras considerações, convida os presentes a se inscreverem como fundadores da Associação Mantenedora do Museu Escolar Nacional.

$\mathrm{E}$ isto imediatamente se verifica, começada a inscrição com o nome do Imperador, e encerrada com o nome de Benjamim Constant.

Já em 5 de outubro se acha instalada a Associação, vindo a ser a sua Diretoria, composta das mesmas figuras que apareciam na Comissão Diretora da Exposição, entre as quais Correia, como vice-presidente.

Por fim, a 2 de dezembro inaugura-se solenemente, com a presença da Família Imperial, e com a assistência de membros do ministério e corpo diplomático, conselheiros de Estado, magistrados, chefes de repartições e senhoras e cavalheiros da melhor sociedade, como refere o Jornal do Comércio do tempo, noticiando essa inauguração. 
No ato, pronunciu o Conde d'Eu, presidente da Associação, interessante e erudito discurso, publicado na íntegra, e que muito recomenda a sua cultura, expondo o plano organizado para a vida da instituição criada.

Louvou ainda a iniciativa individual, a que a mesma se devia, o que tanto honrava ao nosso país.

"Não obstante o apoio com que nos favoreceram os depositários da autoridade pública, que havemos de continuar a solicitar dos representantes da administaçção nos seus diversos graus, é essencialmente de caráter particular a instituição que se inaugura, fruto da iniciativa de alguns e da generosidade dos que se dignaram aderir à idéia. - É ela mais um sintoma dêsse despertar da iniciativa privada que em todos os ramos co progresso se manifesta, aponta para tôdas as direções e se nos afigura mais segura prova de que a nacionalidade brasileira contém em seu seio elementos de pujante vitalidade. Vemos que associações se fundam, que se congregam elementos, que o progresso realiza-se, especialmente em matéria de instrução, sem dependência de aceno do govêrno".

E concluiu com uma viva profissão de fé liberal, contrária ¿े absorção pelo Estado da instrução, da educação, e outros progressos.

Da vida dessa Associação, ou, melhor, do sucesso que ela constituiu, dos serviços que prestou, do favor com que foi recebida pelo público, de tudo isso apresenta longa notícia Paula Freitas no seu citado trabalho, em que registra ainda a luzida e extensa lista dos associados.

E assim sabe, resumidamente, falar Moreira de Azevedo:

"Fundou a Associação uma biblioteca que chegou a contar mais de seis mil volumes, e o museu cêrca de novecentas coleções de objetos; abriu conferências pedagógicas, organizou exposições escolares, e para a instrução pública facultou a Biblioteca e as suas coleções do Museu aos professôres públicos e às pessoas interessadas. Preencheu assim os seus principais fins".

Surgindo porém a República, o Govêrno Provisório funda um estabelecimento de ensino profissional sob a denominação de Pedagogium. 
E a Inspetoria da Instrução Primária do Distrito Federal solicita a entrega dos materiais componentes do Museu, o que faz a Associação, ao mesmo tempo que se dissolve.

E como informa Moreira de Azevedo, foram, no Pedagogium, utilizados os livros, objetos escolares, instrumentos e aparelhos para ensino de diversas disciplinas, coleções para lições tecnicológicas, para lições de coisas, e acessórios de ensino geral.

Mas rápida foi a existência dêsse Pedagogium, alta realização de Benjamim Constant, porém, destroçada pelo legislador, como lamentava Manuel Vitorino na tribuna do Senado, em 1892, ao discutir-se o Orçamento do Ministério do Interior.

$\mathrm{E}$ curioso é saber-se o fim reservado àqueles preciosos especimes, acumulados com tanto esfôrço!... Teria sido o que receava Correia, os das fôlhas de árvores sêcas levadas pelo tufão!...

0 nome de Correia com relêvo, achava-se ainda ligado ao dessa benemérita e sesquisecular Sociedade Amante da Instrução, consagrada ao mesmo tempo ao ensino e à caridade.

A princípio, em 1884, é um dos oradores juntamente com Afonso Celso Júnior (mais tarde Conde de Afonso Celso) e Ferreira Viana, dessa série de conferências realizadas no Asilo de órfãos ali existente; e escolhendo para tema de sua conferência, justamente a história dessa benemérita Sociedade, que seria mais tarde tratada também, e com maior desenvolvimento, por Nascimento Silva, em trabalho publicado na Revista do Instituto Histórico, de 1893.

Em 1887, é quem na tribuna do Senado, com altiloquêencia, defende vitoriosamente uma determinada pretensão da Sociedade, em prol do Asilo.

Depois em 1889, essa mesma Sociedade, em momento difícil por que passa, bate-lhe à porta; elege-o seu presidente.

E do que faz por ela, dá a seguinte notícia Moreira de Azevedo: ampliou o edifício do Asilo, elevando de cinqüenta a cem o número de órfãos que abrigava; fundou o Externato no ter- 
reno do Asilo, mas dêste separado em que recebem instrução gratuita as meninas que o quiseram freqüentar.

Finalmente, passo a falar sôbre aquelas referidas outras situações da sua vida cultural.

Em 1883, é quem promove a fundação da ilustre Sociedade de Geografia do Rio de Janeiro, hoje Sociedade Brasileira de Geografia; e sendo seu presidente nos atos preparatórios.

Em 1886 entra para o quadro do Instituto Histórico, mediante muito honroso parecer da Comissão de História, fazendo logo parte da Comissão de Admissão de Sócios, ao lado de Olegário Herculano e Visconde de Taunay.

Mas até 1889 quase que não assiste às sessões, naturalmente por aquela multiplicidade de afazeres no Senado e nas associações culturais.

$\mathrm{E}$ apenas na sessão de 27 de setembro sobe à tribuna, como orador incumbido de responder ao discurso de agradecimento do sócio honorário, que então se empossou, Dr. Henrique Moreno, Ministro da Argentina, que fôra signatário do importante convênio, então firmado entre o Brasil e aquêle país, sujeitando ao Arbitramento a secular questão das Missões.

Mas, se limitada então foi, por essa forma, a colaboração do ilustre brasileiro naquela Casa, extraordinária haveria de ser depois da proclamação da República, segundo porei de manifesto, na terceira e última parte dêste trabalho.

Chego agora às célebres "Conferências da Glória", como disse a nota mais elevada da atividade cultural de Correia.

Tiravam as mesmas, o seu nome, do local em que eram realizadas, a Escola da Freguesia da Glória (com a República passando a denominar-se Escola José de Alencar), sita então no Largo do Machado, a seguir Praça Duque de Caxias, e voltando afinal ao nome primitivo, depois que a estátua do glorioso soldado, ali erigida, foi transplantada para a Praça da República; c realizavam-se bissemanalmente.

Funcionava essa Escola em prédio de sólida construção, e nobre aspecto, ostentando em seu frontespício a legenda: Ao povo - 0 Govêrno. 
Prédio, o mesmo, que ainda lá se vê, salvo como por um milagre da onda avassaladora que hoje se ergue, por tôdas as formas, de desrespeito ao nosso glorioso passado.

E não é só das "Conferências" em causa, que decorre o seu valor histórico.

Terminada a Guerra do Paraguai, abriu-se uma subscrição popular a fim de ser erigido um monumento ao Imperador, representando-o na rendição de Uruguaiana.

Pediu êle, porém, o sábio e liberal D. Pedro II, que o produto da mesma fôsse aplicado à construção de prédios para condigna instalação de escolas públicas, um dos quais foi êsse da Escola da Freguesia da Glória.

Fundou Correia essas "Conferências da Glória", em 1873, sendo inauguradas a 22 de novembro, como se vê na citada Compilação de Santos Cardoso - Conferências e outros trabalhos do Conselheiro Manuel Francisco Correia, publicada em 1885.

No discurso que então proferiu disse êle:

"Concebendo a idéia de fazer estas conferências para entreter-vos com assuntos que nos possam interessar, sem transpor a região serena em que se debatem as questões que a todos tocam, mas extremes das paixóes políticas e de outras que se agitam no seio da sociedade, e a perturbam pela divisão de urenças e princípios, tive a fortuna de vê-la benèvolamente acolhida pelo augusto protetor de todos os cometimentos úteis, que veio honrar com a sua presença os esforços que fazemos a bem da causa pública, e a quem devo assim, bem como a Sua Majestade a Imperatriz por seu animador comparecimento, a minha primeira palavra de gratidão".

E foi a proteção que D. Pedro II, desde êsse momento até a queda do Império dispensou a essas Conferências, a que comparecia, a causa principal de seu sucesso, da sua longa e tão proveitosa existência.

A exibição perante o Imperador constituia um estímulo para os conferencistas; fazer uma conferência na Escola da Glória era uma consagração. 
Aliás - de par com o culto o mais escrupuloso, da Justiça e da Liberdade - o culto da Instrução, na proteção constante, e por tôdas as formas, às ciências, às letras, às artes, formavam um dos títulos que imortalizam a figura do Príncipe ilustre que por meio século governou o Brasil, para a sua glória e para a glória das Americas, e a ecoar no Velho Mundo.

Depois daquele discurso inaugural, deixou Correia bem justificada a instituição das Conferências em causa, na que proferiu em Niterói a 5 de junho de 1874 .

Mostrou o que ocorria a respeito em outros países (nos quais as Conferências públicas constituiam "o meio incessante de despertar o espírito", nas quais homens dos mais eminentes, como, por exemplo, na França, Guisot, Cousin, Júlio Fabre e Laboulaye e, na Inglaterra, a terra clássica dos meetings, Cobdeni, Pakington, Bright, e Gladstone, consideravam útil, importante ocupação de tempo dirigirem-se ao povo da tribuna das mesmas.

No seu referido Esbôço Biográfico assim resume Amaro da Silveira a vida dessas históricas "Conferências da Glória", até 1884:

"A tribuna da escola da Glória... completou em novembro de 1884, onze anos de existência, contra tôdas as previsões que na época de sua inạuguração ameaçavam-na de malôgro".

"Franqueada aos cidadãos de tôdas as classes... esta tribuna conseguiu, entretanto, manter até o presente, no desempenho de seu difícil programa, um assíduo concurso de oradores, constituindo-se muitas vêzes órgãos de generosas idéias, em benefício do progresso nacional".

"Entre os cidadãos que a tem frequentado, realizando 500 conferências, pela maior parte destinadas à divulgação de conhecimentos úteis ou ao estudo de questões relacionadas com o interêsse público, encontram-se representantes das nossas academias e das nossas escolas primárias; das nossas assembléias políticas e das nossas classes industriais, das nossas armas e das nossas letras; e os nomes de alguns dêles, se fôsse possível desprezar em tal caso a mais humilde colaboração correspondeu aos desígnios de seu iniciador". 
Essas 500 Conferências foram realizadas por 111 oradores, cujos nomes, bem como o número das que cada um proferiu, constam de uma Relação fornecida pelo próprio Correia, publicada por Santos Cardoso, em anexo ao seu referido volume - Conferências e outros trabalhos do Conselheiro Manuel Francisco Correia.

Relação essa deveras luzida, onde se podem ver, por exemplo, nomes como os que passo a citar, pela ordem cronológica, seguida na mesma e com os qualificativos de então: Conselheiro João Manuel Pereira da Silva, Dr. Antônio Ferreira Viana, Conselheiro Joaquim Caminhoá, Dr. Nuno Ferreira de Andrade, Senador José Martins da Cruz Jobim, Dr. Antonio Coelho Rodrigues, Barão de Tautpheous, Desembargador Tristão de Alencar Araripe, Dr. José de Saldanha da Gama, Conselheiro José Liberato Barroso, Dr. Joaquim Murtinho, Conselheiro Antônio de Almeida e Oliveira, Dr. Joaquim Aurélio Nabuco de Araújo, Dr. Antônio Herculano de Sousa Bandeira Filho, Doutor Afonso Celso de Assis Figueiredo Júnior, Dr. Amaro Cavalcanti, Dr. Silva Araújo, Dr. Antônio de Castro Lopes, Senador Afonso Celso de Assis Figueiredo, Dr. José Carlos de Moura Brasil, Dr. João Barbosa Rodrigues, Dr. Benjamim Franklin Ramiz Galvão, Dr. Cipriano de Freitas, Dr. Hilário de Gouveia, Doutor Rozendo Muniz Barreto, Dr. J. Joaquim Meneses Vieira, Doutor Tomás Alves Júnior, Dr. Antônio Felicio dos Santos, Doutor Carlos Frederico Hartt, Dr. José Pereira Rêgo Filho.

Infelizmente, a não ser quanto as de Correia, muito poucas das 500 Conferências realizadas correram impressas, e muito difícil sendo hoje encontrá-las.

Mas o valor dos oradores deixa ver, de fato, o que teria sido a influência que teriam exercido no progresso do país.

Quem fêz o maior número de Conferências foi êle próprio, Correia; contam-se por cinqüenta.

Entre as mesmas vejam-se, por exemplo, as que se seguem: Énsino Primário obrigatório; Importância das Conferências Fúblicas; Riqueza intelectual; Direção do ensino; Não é monopblio do Estado o ensino superior; Educação da mocidade; 
A igreja e a escola; Liberdade de consciência; A Educação na família e na escola; Os edifícios escolares; Proscrição dos castigos corporais; Educação das crianças das ruas; Ensino moral; Religião; Família; Positivismo; Materialismo; Necessidades de escolas normais; Caridade e instrução; Necessidade de um museu escolar; Educação física; Criação de uma universidade; Congresso de instrução; Batalha do Riachuelo.

A estreiteza do tempo não me permite apreciar, aqui, detalhadamente essas Conferências, em que a revelação da sua importância começa pelos próprios sugestivos títulos que as encabeçam.

Apenas direi que Correia versou, com muito brilho, relevantes problemas pedagógicos, sociais e morais, de amplo quadro.

Versou com lições as mais adiantadas e mais sadias e mostrando perfeito conhecimento do que sôbre o assunto das mesmas ocorria nos diversos países; lições que tanto lhe honram a memória, e algumas das quais ainda se impondo, agora, para soerguer a geração atual, contaminada pelo agnosticismo, cu ainda pior pelo materialismo.

E do patriotismo que as animava e da eloqüência com que foram proferidas, vivo exemplo é o dessa Conferência por êle, Correia, realizada em 11 de junho de 1882, sôbre o feito heróico da Batalha do Riachuelo, em que o Brasil cobriu-se de glória.

Já bem soube a Comissão de História, em 1886, pronunciando-se pela entrada do ilustre brasileiro para o Instituto Histórico:

"Eram passados dezesseis anos e ainda parecia ouvir-se ali o estampido do canhão de duas esquadras, uma triunfante, cutra destroçada, e envôlto nas aclamações da vitória o hino do Riachuelo, a mais gloriosa batalha naval que se feriu na América do Sul e que assegurou o triunfo da sua civilização ameaçada pelos gaúchos da tirania".

Dir-se-ia que o orador se retraíra dezessete anos, e achava-se nesse dia em que a nova da famosa batalha chegou ao 
Rio de Janeiro, entusiasmando todos os brasileiro que se abraçavam pelo grande triunfo alcançado pela armada nacional nas águas do Paraná; êsse dia em que se ouviram as narrativas das batalhas do Prata com as lágrimas de comoção patrióticas a se deslizarem dos olhos com o entusiasmo da glória a palpitar nos corações".

Não se limitou porém, às Conferências as atividades de Correia na tribuna da Escola da Glória.

Ei-lo em 17 de junho de 1881, a significar na mesma:

"É meu sincero desejo que entre as vantagens que se possam porventura colher desta tribuna conte-se a de nela ecoar 0 louvor a todo cometimento que traga brilho ao nome brasileiro com uma saudação digna do patriota que o realizar. - Os benefícios da humanidade são sempre apreciáveis. - Se a minha admiração e o meu aplauso são sempre os mesmos, há graduações no seu contentamento pessoal, conforme 0 benefício e feito no estrangeiro por estrangeiro, no Brasil por estrangeiro, no estrangeiro por brasileiro e no Brasil por brasileiro. Nêste último caso todos os meus votos ficam preenchidos".

E assim passando a saudar o Dr. João Batista de Lacerda, "pelo humanitário benefício de sua descoberta contra a peçonha das cobras".

E pela mesma forma saudará, por exemplo, no dia 21 de junho o Dr. Antônio de Castro Lopes, por haver descoberto "os meios de aumentar a fôrça dos telescópios"; em outra data dêsse ano, o Dr. Cruls, "cidadão brasileiro naturalizado, diretor interino do Observatório Astronômico, que por estudos acêrca do cometa de 1887, estudos reveladores de proveitosa aplicação de sólidos conhecimentos, tanto lustre deu àquele nosso estabelecimento"; a 21 de maio de 1882, o lente de química orgânica Dr. Domingos Freira, pelos seus "laboriosos esforços, mais uma vez coroados de êxito feliz, com o descobrimento de processo científico para a conservação perfeita de certas substâncias, com grande proveito para a alimentação do povo".

$\mathrm{E}$ muito especial registro merecendo, afinal, as palavras que, a 29 de maio de 1881, em tôrno da figura de Júlio Cesar 
Ribeiro de Sousa proferiu sôbre o magno problema da navegação aérea, vivamente confiante na sua breve e completa solução, mercê do progresso da ciência. ,

"Manifesto essa confiança", proclama êle, "porque não reputo mais difícil vencer os obstáculos a essa navegação do que remover os que outrora se opunham à navegação de longo curso. Quem corta livremente os mares, ainda que revoltos, atravessará também com afouteza os ares, onde já penetra embora tìmidamente".

"Em busca de solução para tão momentoso problema, tem consumido o tempo, o dinheiro, e a paciência, o distinto paraense Júlio César Ribeiro de Souza que se há tornado digno de tôda animação, tanto mais quanto parecer a julgar pela opinião de competentes autoridades, que êle deu um passo, conquanto não o decisivo, para a conquista do notável melhoramento".

"Para prosseguir no seu nobre empenho, convém que êste se dirija à Europa onde encontra mais vasto campo para sua atividade.

Necessita porém de meios pecuniários, e não muito consideráveis.

A munificência de S. M. o Imperador já se manifestou; mas não é demais que concorram todos para que se torne prática a idéia de Júlio César, que se conseguir o seu intento, tão cheio de benefícios para a humanidade, fará com que não se apague na lembrança dos homens o lugar em que foi o Brasil, ainda que um cataclisma venha a varrer da superfície do globo a região dêste vasto império".

"Não é possível esquecer nêste momento, que foi um brasileiro, Bartolomeu Lourenço de Gusmão, o descobridor do meio rudimentar de que os homens se têm servido para empreender a viagens pelo espaço. Seria por fortuna o anúncio providencial de que caberá à nossa Pátria a glória imarcessível da completa transformação social que tem de operar a navegação aérea".

Se não coube a Júlio César realizar êsse máximo anseio de Correia, assinalado ficou porém o seu nome entre os pioneiros da Aeronáutica. 
Naquele mesmo ano, como em seu "Dicionário Bibliográficc" Blake deixa em foco, realizara êle a sua primeira ascenção em Paris, perante os mais notáveis aeronautas franceses e grande massa de povo, e uma segunda logo depois "contra o vento e sem auxílio de propulsor algum", demorando-se no ar cêrca de três horas. Regressando ao Brasil, fêz ainda duas ascensões, uma no Pará e outra no Rio de Janeiro, em ambas com os mais felizes resultados e aplausos. Tornou à Europa, alí construiu novo e maior balão, com o qual tornou à Pátria, ro mesmo porém não podendo viajar, por um lamentável acidente que o destruiu".

Tudo isso informa Blake concluindo: "Foi sem dúvida alguma um aperfeiçoador da navegação aerostática e seu invento obteve privilégio nos Estados Unidos e em vários Estados da Europa, oferecendo-lhe a Rússia grandes vantagens pela compra dêle".

Mas se não lhe coube, a Júlio César, realizar, assim o máximo anseio de Correia, a um outro brasileiro haveria de caber - ao glorioso Santos Dumont.

$\mathrm{E}$ quis o destino, como para adiante deixarei visto, que o próprio Correia o houvesse de saudar, quando o Instituto Histórico, jubiloso, abriu as suas portas para receber o Triunfador do Ar!

\section{III}

Passo agora, na conformidade do plano estabelecido, a estudar a figura do ilustre brasileiro na República, sob todos os seus aspectos e a começar pelo político.

Foi do partido conservador de São Paulo que partiram, e imediatamente, as primeiras adesões ao 15 de novembro.

Isto pelo que respeita aos componentes de "União Conservadora", chefiada pelo ilustre Conselheiro Antônio Prado, o qual aliás desde algum tempo já vinha manifestando certo pendor democrático; e não pelo que respeita à "Dissidência Conservadora", chefiada pelo ilustre jurista João Mendes de Almeida, 
pois esta não cedeu, antes constituiu-se um reduto de inabalável fé monárquica.

Ao lado de Antônio Prado e outros, coparticipou dessa adesão o ilustre parlamentar e jornalista, e mais tarde professor, Almeida Nogueira, então redator do Correio Paulistano, e que logo expediu uma carta circular a diversos próceres dos antigos partidos do Império, com a seguinte pergunta: "Devem os brasileiro conformar-se com o atual estado de coisas"?

E a resposta de Correia não se fêz esperar, consta dessa carta por êle escrita a 28 de novembro, publicada então no Correio Paulistano, e pelo mesmo Almeida Nogueira transcrita mais tarde nas suas clássicas Reminiscências da Faculdade de Direito de São Paulo.

Nela declara Correia:

"Tenho para mim que, nas presentes circunstâcias do Brasil, não aproveitaria à causa pública a restauração monárquica".

"É consequência: que os brasileiros temos que nos conformar com o atual estado de coisas".

"Na pacífica anuência que por tôda a parte se nota não vejo ato de pusilanimidade: seria dar ao caráter nacional feição repugnante".

"Se não é condenação do regime anterior (e eu aceito inteira a responsabilidade da parte, embora pequena, que nela me cabe) essa anuência exprime a esperança de que o regime republicano não será desfavorável ao engrandecimento da pátria, que assenta na integridade nacional; e esta reclama a reunião, no mais curto prazo que fôr possível, de uma assemblẻia constituinte por meio da qual a nação manifeste a sua vontade quanto à organização definitiva da República".

E faz sentir que, se para essa assembléia o mandato legislativo lhe fôsse espontâneamente renovado, não se recusaria a servir ao Brasil, como nunca se recusara no passado.

Seguindo os ditames de sua consciência, resolveu por essa forma colaborar na Repúbliça. 
E fôrça é dizer que se, no Império, pertencia êle ao partido conservador era entretanto tolerante e progressista, e, como se viu, mais preocupado com os problemas culturais do que com os problemas políticos.

Afinal aceita mesmo, em 1893, a nomeação para Presidente do Tribunal de Contas criado pelo Constituição, e que então se instalou; cargo para o qual se recomendava por todos os títulos.

Aceita êsse cargo, para servir ao Brasil, atendendo ao convite em têrmos os mais honrosos que lhe foi feito pelo ilustre Ministro da Fazenda, Serzedelo Correia; e o aceita nos têrmos os mais dignos e os mais elevados do discurso que profere ao instalar-se o Tribunal, como pode ser visto da Memória por êle escrita sôbre a matéria e publicada na Revista do Instituto Histórico em 1894.

Mas os tempos tinham mudado.

No liberalismo do Império, absoluta era a liberdade de crenças políticas, e republicanos confessos e militantes tinham acesso às câmaras Legislativas e a cargos públicos.

Benjamim Constant pregava a República, na Escola Militar, de que era Diretor.

E na excursão que o Príncipe Consorte, Conde d'Eu, faz pelas províncias do Norte, Silva Jardim o acompanha, pelo mesmo navio, efetuando conferências republicanas em todos os portos em que êle descia.

Coisas semelhantes não eram permitidas então.

E mais grave se tornou ainda a situação, com a Revolta dà Armada de 6 de setembro daquele ano.

Surge a treva do estado de sítio.

E tudo passa a ser suspeito.

O próprio ex-Ministro da Fazenda Serzedelo Correia figura republicana que tanto vinha se destacando, é reconlhido a uma fortaleza.

Cái o rạio sộbre Correia; o Govêrno o destitui do seu cargo! 
E outro ráio ainda mais o fere, o do trucidamento do seu digno irmão e maior amigo, o Barão de Sêrro Azul, e sem que os agentes do Govêrno participantes do hediondo crime fôssem punidos!

Amargurado por essa forma, mas sempre forte de espírito, deixando o cargo que ocupava, volta êle a prosseguir na brilhante e indefesa atividade na vida cultural do país.

Como já antecipei, se essa atividade no Instituto Hstórico, foi limitada ao Império, extraordinária seria na República.

De fato.

Continua na Comissão de Admissão de Sócios, e chegará a 1. Vice-Presidente da Casa; desempenha diversas Comissões especiais, é dos sócios mais assíduos às sessões e à tribuna, a que sobe espontâneamente, ou na ausência do orador oficial, faz comunicações, e diversos trabalhos e memórias de sua autoria ainda aparecem na Revista.

Dêstes trabalhos e memórias, são de maior importância, os que, pela ordem cronológica, passo a citar e apreciar.

Circular do Govêrno do Império aos Representantes no estrangeiro, sôbre a lei de 28 de setembro. A importância da mesma, que aliás é sucinta, e expedida foi por êle, Correia, quando Ministro dos Negócios Estrangeiros, decorre do seu cbjeto, da sua forma, e do seu momento.

Era nuncia aos países estrangeiros, de um grande acontecimento, que tanto honrava o Brasil, o da libertação dos filhos a nascer da mulher escrava; estava hábilmente redigida, atribuindo a uma razão política, a da oportunidade, e não a um propósito menos nobre, a oposição que teve de vencer essa humanitária Lei de 28 de setembro, nas Câmaras Legislativas. E, de fato, quanto à Europa, chegava no momento em que o Brasil estava em foco, mercê da excursão que por lá realizava c. Imperador.

Memória sôbre o Tribunal de Contas. Aí trata êle de sua destituição da presidência dêsse alto Tribunal; e envolvendo o histórico da instalação do mesmo. 
1

Explicações reclamadas pelo $3 .^{\circ}$ Tomo da Obra do Dr. Joaquim Nabuco. Um Estadista do Império. Nesse trabalho visou responder às argurições de Joaquim Nabuco, às quais anteriormente me referi, de que as negociações realizadas no Ministério dos Estrangeiros, quando êle Correia era o seu titular, sôbre assuntos do Prata, foram obra direta do Visconde do Rio Branco.

Missão Especial do General D. B. Mitre no Brasil em 1872. Interessante documento histórico sôbre assuntos do trabalho anterior.

Memória auto-biográfica escrita em 1890, onde aparecem informes sôbre a agitada questão militar de 1887, sôbre a procJamação da República, e explica êle a atitude que tomou em face desta, e que idéias sustentaria sôbre a organização do novo regime se eleito fôsse para a Assembléia Constituinte.

Exposição acêrca dos fatos que se deram nas vésparas da República.

Esse trabalho de que falarei mais longamente, como se impõe, prende-se a Memória lida em sessão anterior do instituto.

No mesmo, assim começa Correia :

"Nos aziagos dias 15, 16 e 17 de novembro de 1889, o imperador esteve sempre na altura da dignidade do eminente cargo".

E passa a narrar:

"Pouco antes de 7 da tarde de 15 de novembro o Imperador dignou-se manifestar o desejo de ouvir-me a sós, em gabinete particular, acêrca dos memoráveis fatos dêsse dia".

"A conversa versou sôbre a natureza e o alcance dos acontecimentos, não perdendo o imperador um só instante a serenidade que o caracterizava, quando depois de expor-lhe o que sabia por haver presenciado, tive de entrar com a costumada lealdade no delicado ponto relativo à sua ilustre pessoa e à sua augusta família".

"Fácil será de imaginar a amargura com que em presença sòmente do varão respeitável ví-me obrigado a referir com verdade a situação". 
"Paguei um doloroso tributo que a solenidade no momento ainda mais me impunha".

"Não notei no semblante do Imperador o mais leve sinal de despeito ou cólera".

"Às suas palavras graves como de costume foram no fim quais as primeiras".

"Em ocasião de tanta angústia o Imperador soube guardar consigo o pensamento intimo, interrogou, ouviu, refletiu e conservou-se inalterável".

"Guardo ainda bem viva a impressão dessa conferência que para mim pôs à prova a rígida têmpera de caráter do Imperador".

"Presto-lhe assim mais uma homenagem de minha admiração".

Transcritas essas palavras da Memória, passa êle Correia a comentá-las, isto é, a referir o que interrogou, ouviu e repletiu o Imperador.

Do mais alto valor histórico, é, pois, êsse trabalho de Correia - Exposição acerca dos fatos que se deram nas vésperas da República, e no qual fica à vista a consideração política e pessoal que o Imperador dispensava a Correia.

Revela, a tôda luz, a dignidade e a serenidade com que, $\mathrm{em}$ momento tão angustioso de sua vida, se houve aquêle a quem a justiça da História já proclamou "O Magnânimo"; e presta interessantes informes sôbre o feito de 15 de Novembro.

Não me permite o tempo fazer apreciações sôbre os seus pareceres emitidos nas Comissões especiais a que pertenceu.

É que preciso passar ao trato da figura que representou na tribuna do Instituto; certo que foi êle primordialmente 0 homem da tribuna, como anteriormente deixei visto, revelado já na mocidade em São Paulo, quer na tribuna acadêmica, quer na popular, e a seguir no Parlamento, e nas "Conferências da Glória".

Merece, desde logo, especial registro o belo e conceituoso discurso que na Sessão Magna de 1892, proferiu sôbre a alta 
missão da História e o brilho com que o Instituto, de sempre a vinha realizando.

Subiu ainda à tribuna pela recepção de ilustres sócios, exaltando sobretudo as figuras de Joaquim Nabuco, Santos Dumont, Euclides da Cunha, e Júlio Maria, com discursos que não foram longos, mas inspirados, como sempre, nêste sentido, subndo de ponto o que proferu sôbre Santos Dumont.

Àquele que, tempos antes, em tôrno da figura de Júlio César já ansiava para que à nossa Pátria coubesse a glória da solução definitiva do problema da navegação aérea, de que 0 primeiro passo já havia sido dado por um brasileiro, Bartolomeu de Gusmão - transportado de júbilo saúda a vitória de Santos Dumont.

Assim começa:

"A maior descoberta que em proveito da civilização e para hem da humanidade podia assinalar o século XX, era a do balão. Vós realizastes essa aspiração, que revoluciona em seus pontos fracos a ordem social existente". mem"!

"Que glória de mais relêvo poderia ambicionar um ho-

"Querendo a sorte propícia que êsse homem seja compatriota nosso, não é justo o desvanecimento dos brasileiros"?

E para prosseguir:

"A vossa tarefa, porém, não está concluida. Transpusestes a grande barreira".

"Sois o piloto do ar. Correis por êle livremente. Brincais com êle".

"Podeis surpreender uma evolução militar desfraldando nas alturas a bandeira vossa, de nossa pátria".

“É muito, é realmente muito, mas não é tudo, são notáveis os progressos do Santos Dumont $n . .^{\circ} 1$, ao Santos Dumont n. ${ }^{\circ}$ 9, o Santos Dumont $n .{ }^{\circ} 10$ abre já mais fecunda rota para as viagens futuras".

"Com a rapidêz vertiginosa da vossa atividade, em os anos dilatados que a Providência vos reserva, jovem que sois, quan- 
tos benefícios não terá de receber a navegação aérea de vossa proverbial solicitude".

"A imaginação vislumbra os proveitos que, para a raça humana, alcançará o Santos Dumont n. ${ }^{\circ} 2{ }^{\prime}$.

"Não há em todo o mundo civilizado quem não vos conheça e não alimente a esperança das novas vitórias que vos aguardam".

"Os que aqui jubilosos vos acolhemos estamos certos de que não desfalecereis na jornada, que prosseguireis com afã na obra com todo o brilho encetada, levareis a cabo a portentosa emprêsa".

"Não o Brasil só, mas tôdas as nações têm, Sr. Santos Dumont, os olhos fitos em vós".

E a previsão de Correia não falharia.

Santos Dumont, afinal, amplia gloriosamente o seu invento, no campo "do mais leve do que o ar", passando para o "do mais pesado de que o ar".

Mas o entusiasmo de Correia pelas conquistas da ciência, ainda aquelas provindas de estrangeiros, e no estrangeiro, o levara também à tribuna antes, em 1898 na sessão extraordinária pelo Instituto celebrada, em homenagem à expedição belga ao polo sul, em trânsito pelo Brasil.

$\mathrm{E}$ os seus títulos oratórios e a largueza de sua cultura geral como sempre, ficam à prova nos belos lances, do discurso que profere fazendo votos pelo sucesso da mesma expedição.

Vou considerar, agora, as Conferências Populares, isto é, as "Conferências da Glória", que já apreciei pelo que foram sté 1884 , e que desde 1885 se haviam deslocado para a Sociedade Promotora da Instrução, da qual era êle próprio, Correia, o presidente e que com o mesmo sucesso que tinham, continuaram até a queda do Império.

Subsistiram elas na República, mas fôrça é dizer, sem atração igual a que era determinada pela assistência de D. Pedro II. 
Certo porém que, da parte de Correia, a sua atividade nas mesmas Conferências continuou sempre com todo o brilho e extremada dedicação até que êle em 1905 falecesse; e atividade que somou por três décadas!

Ao lado de tôda essa obra extraordinária, que ia realizando, no Instituto, e nessas Conferências Populares, como ainda na Sociedade Promotora da Instrução, foi eleito sócio, \& logo presidente da histórica Sociedade Auxiliadora da Indústria Nacional que contava no seu acervo a glória da fundação desta Casa; tôdas as associações do gênero solicitavam sempre os seus altos serviços.

Finalmente, em 1901, a sua cultura jurídica fica muito em foco, a respeito do Projeto do Código Civil.

É um dos juristas convidados, pela respectiva comissão da Câmara dos Deputados, para tomar parte nos estudos.

Clóvis Beviláqua, em nota aos seus Comentários ao Código Civil, ao citar os nomes dêsses convidados, o coloca logo em seguida a Andrade Figueira e Coelho Rodrigues.

Comparecendo a primeira reunião da mesma Comissão, pronuncia Correia, de início as seguintes palavras: "Senhores €m uma das minhas muitas Conferências que correm impressas lê-se: "Os brasileiros sabemos que para o serviço da Pátria, o cidadão só perece quando a luz se lhe apaga dos olhos".

Com êsse ânimo, é que passa a trabalhar, e para deveras salientar-se.

Trata longamente do "Direito de Família", sob os seus variadoes aspectos, e de modo considerável, do "Direito Autoral". E aborda problemas tanto da Introdução do Projeto, como da Parte Geral, do Direito das Coisas, do das Obrigações, e do das Sucessões.

Deve-lhe assim o Brasil, mais êste assinalado serviço.

Essa que acabo de descrever, foi a vida do Conselheiro Manuel Francisco Correia, mais conhecido por Senador Correia; longa vida de brilhante e indefessa atividade, pela causa da Cultura e pela causa da Pátria. 